\title{
The Influence of Implementing Discussion Method On Enhancing Students' Motivation In Learning Sosial Study In Medan Mulia Elementary School
}

\author{
Shinta Dharma Hardi \\ \{shinta.hardi@yahoo.com\} \\ Sekolah Tinggi Teologi Pelita Kebenaran Medan
}

\begin{abstract}
This research is aimed at enhancing the students' motivation in learning Social Study by using discussion method. The problem of this study is how the fifth grade students' motivation can enhance in learning Social Study by implementing the discussion method. The purpose of this study is to enhance the fifth grade students' motivation in learning Social Study in Medan Mulia Elementary School. This research used the classroom action research which consisted of four steps, namely: planning, implementing, observing, and reflecting. The technique of data gathering is by doing observation, then, for the data analysis, the writer used data reduction, data presentation, and data verification. The results of the study were: the students' activeness in completing their homework has increased $21,43 \%$, in studying the lesson has increased $35,71 \%$, in question and answer session has increased $35,71 \%$, in obeying school rules has increased $42,86 \%$, in completing school assignments has increased $35,71 \%$. It can be concluded that the implementing of discussion method can enhance the fifth grade students' learning motivation in Medan Mulia elementary school.
\end{abstract}

Keywords: Discussion Method, Enhancing, Sosial Study

\section{Introduction}

Discussion is the verbal interaction process of two people and they face each other while discussing certain purpose, defending opinions or solving problems. Discussion can be interpreted as scientific meeting to share about one matter. While using discussion method, teacher gives the opportunity to students (groups of students) to talk about scientific matter in order to gather opinions, draw conclusion, or working on several problems solving that can be in statements or questions. In discussion students work on one topic and each student in the group has the same opportunity to ask and give opinion. Based on that, discussion can be called as participatory method. Students' low motivation could be affected by inactive learning process. Teacher-centered learning process could cause monotonous situation and students lack motivation to study. The students' low motivation in learning could be influenced by the monotonous learning method that causes the boredom among the students so that the expected study result is difficult to obtain.

Table 1. The table of the assumptions of problem causes :

\begin{tabular}{ccl}
\hline No & Factor & \multicolumn{1}{c}{ Problem Cause } \\
\hline 1 & STUDENTS & The students think that Social Study is a difficult subject \\
2 & TEACHER & $\begin{array}{l}\text { Some of the teachers still use the lecturing method, the students are passive } \\
\text { and unmotivated to study the learning material at home } \\
\text { The learning process is focused on the teacher and not democratic so that the } \\
\text { students are not encouraged to participate in the learning process }\end{array}$ \\
\hline
\end{tabular}




\begin{tabular}{lll}
\hline 4 MATERIAL & $\begin{array}{l}\text { The Social Study material is complex and covers a lot of lessons so that the } \\
\text { students can understand only a bit of the lessons }\end{array}$ \\
\hline
\end{tabular}

One of the ways to motivate the students is by holding discussion. Group discussion could make the students more active in learning process because could result in good competition among the students. The process could happen in discussion or discovering new data through data collection. The data could be obtained by doing experiment or gathering the data from the location. Discussion method is appropriate in Social Study and could motivate the students to be more active in learning activity.

\section{Research Method}

The research was done in grade 5 in Medan Mulia school. The research was performed in two cycles and the learning material was the descriptions of the heritage of Hinduism, Buddhism, and Islam era in Indonesia. The subjects of the research were 30 students, 16 male students and 14 female students. This research was classroom action research and was performed in 2 cycles and each cycle consisted of two meetings. This research was performed in four steps of research, namely: planning, implementing, observing, and reflecting.

The steps of the rearch were as follows:

1. Cycle I

a. Preparation step

b. Performing step

c. Observation step

d. Reflection step

2. Cycle II

a. Planning step

b. Performing step

3. Observation step

The observation was done during the learning process. The observation aspects were the students' activities and creativities in understanding the lesson while the teacher was delivering the lesson or when students were discussing. The observation was done by using observation sheet. The purpose was to understand the students' activeness in learning process, then the students' grades were gathered by using written test.

4. Reflection step

Reflection was done after the remedial action based on the the reseacher's records during the learning process. Reflection is aimed at understanding the weaknesses in teaching and to know the students' ability in understanding the lesson material. Discussion method could enhance the students' achievement in describing the heritage of Hinduism, Buddhism, and Islam in Indonesia

\section{Result And Discussion}

\subsection{The results of the research}

This research was performed in two cycles which consisted of two meetings. Based on the students' achievement which were gathered during the research, there was an increase in 
Social Study achievement after using the discussion method. The table below showed the students' achievement in learning Social Study at the beginning, cycle 1 and cycle 2.

Table 2. The Students' Achievement in Learning Social Study at the beginning, cycle 1 and cycle 2

\begin{tabular}{|c|c|c|c|c|}
\hline $\mathrm{NO}$ & $\begin{array}{l}\text { Grade } \\
\text { Range }\end{array}$ & The Beginning Data & $\begin{array}{c}\text { Students' } \\
\text { Achievement in Cycle } \\
1\end{array}$ & $\begin{array}{c}\text { Students' Achievement } \\
\text { in Cycle } 2\end{array}$ \\
\hline 1 & $<50$ & 8 Students $(36.36 \%)$ & 4 Students $(9.09 \%)$ & 0 Students $(0.00 \%)$ \\
\hline 2 & $51-60$ & 5 Students $(18.18 \%$ & 4 Students $(9.09 \%)$ & 0 Students $(0.00 \%)$ \\
\hline 3 & $61-69$ & 7 Students $(9.09 \%)$ & 5 Students $(9.09 \%)$ & 0 Students $(0.00 \%)$ \\
\hline 4 & $71-80$ & 6 Students $(27.27 \%)$ & 9 Students $(40.91 \%)$ & 13 Students $(36.36 \%)$ \\
\hline 5 & $81-90$ & 2 Students $(4.55 \%)$ & 5 Students $(18.18 \%)$ & 8 Students $(22.73 \%)$ \\
\hline 6 & $91-100$ & 2 Students $(4.55 \%)$ & 3 Students $(13.64 \%)$ & 9 Students $(40.91 \%)$ \\
\hline Tota & O Students & \%) 30 Students $(100$ & 30 Students $(100 \%)$ & \\
\hline \multicolumn{5}{|c|}{73,90} \\
\hline
\end{tabular}

Based on the above table it is clear that the students' achievement has increased in each cycle. In the beginning data, the number of students obtained grades in interval of 91-100 were 2 students (4.55\%), in interval of 81-90 there were 2 students (4.55\%), in interval of 71-80 there were 6 students $(27.27 \%)$, in interval of $61-70$ there were 7 students $(9.09 \%)$, in interval of 51 60 there were 5 students $(18.18 \%)$, and in interval of $<50$ there were 8 students $(36.36 \%)$. In the first cycle the students' study results has increased in intervalof 91-100 there were 3 students (13.64\%), in interval of 81-90 there were 5 students (18.18\%), in intervalof 71-80 there were 9 students $(40.91 \%)$, in interval of $61-70$ there were 5 students $(9.09 \%)$, in interval of 51-60 there were 4 students $(9.09 \%)$, and in interval of $<50$ there were 4 students $(9.09 \%)$. In the second cycle the students' study results has increased in interval of 91-100 there were 9 students (40.91\%), in interval of $81-90$ there were 8 students $(22.73 \%)$, in interval of $71-80$ there were 13 students $(36.36 \%)$, in interval of $61-70$ there was 0 student $(0.00 \%)$, in interval of $51-60$ there was 0 student $(0.00 \%)$, and in interval of $<50$ there was 0 student $(0.00 \%)$.

\subsection{The Discussion}

By using discussion method the students were asked to participate more actively and they became more brave to share their opinions and give questions because the students were given opportunity to discuss freely with their groups. By putting the students into heterogeneous groups and by selecting the smart students to become leaders in each group students felt that there was competition to obtain good grades.

\section{Conclusion}

Based on the result and discussion above, the writer can conclude that the implementation of discussion method can enhance the fifth grade students' study results in learning the subject of Social Study in Medan Mulia Elementary School

1. Based on the data before the research was performed, the students got low grades in Social Study subject in the lesson about the descriptions of the heritage of Hinduism, Buddhism, and Islam in Indonesia. The average grade of the students who could obtain the Minimum Criteria of Passing Grade was 61.35. 
2. Based on the data after the first cycle of the research was performed by implementing the discussion method, only 12 students or $27.28 \%$ of the students in the class did not obtain the Minimum Criteria of Passing Grade with the average grade 73.90 . There were 20 students or $63.64 \%$ of the students in the class who did not obtain the Minimum Criteria of Passing Grade before the remedial treatment was performed. After the second cycle of the research was performed, $100 \%$ of the students could obtain the Minimum Criteria of Passing Grade with the average grade 87.75 .

\section{References}

[1] Ahmadi, Abu. Teknik Belajar Yang Efektif. Jakarta: PT. Hilton, 1991.

[2] Putra.Anni. C.T. Psikologi Belajar. Semarang: PT.Unnes, 2006.

[3] Press Depdikbud. Kamus Besar Bahasa Indonesia. Jakarta: Balai Pustaka, 1990.

[4] Putra Wiranata, dkk. Strategi Belajar Mengajar. Jakarta: Universitas Terbuka, 2004.

[5] Sujana. Nana. Penilaian Hasil Proses Belajar Mengajar. Bandung: PT. Remaja Rosda Karya, 2004

[6] Usman, dkk. Pengantar Psikologi. Bandung: AngkasaUsman, 1985.

[7] Moh.Uzer. Menjadi Guru Profesional Bandung: PT. Remaja Rosdakarya, 2005.

[8] Werkanis,AS. Strategi Mengajar dalam Pelaksanaan Kurikulum Berbasis Kompetensi. Pekanbaru: Sutra Bente, 2005.

[9] Perkasa, Djamarah. Proses Belajar Mengajar. Jakarta: Renneke Cipta, 2006.

[10] Purwanto. Prinsip-prinsip dan Teknik Evaluasi Pengajaran. Bandung, 2008. 